\title{
Optimization of physical culture lessons in primary school on the base of mobile games' application
}

\author{
Shuba L.V. \\ Zaporozhye National Technical University
}

\begin{abstract}
Purpose:

to improve methodic of mobile games' application for physical culture lessons' optimization in primary school that would facilitate motor fitness increase.

Material: $\quad$ in experiment 50 boys (7-9 yrs) from main health group (no health problems) participated. For training strength we chose games, which required short speed-power tensions with at moderate loads. The following objects were used: filled ball, dump bells, benches or partners. In games with overcoming own weight we used: wall bars, beams, vertical rope.

Results: $\quad$ peculiar features of the improved methodic are as follows: for preparatory part we worked out ten separate complexes of general exercises in game form; for all parts of lesson mobile games were selected so that they should facilitate maximal development of physical qualities; each training was emotionally positively colored that motivate pupils' wish to attend the lessons.

Conclusions: for effective development of physical qualities the decisive factor was consideration of sensitive periods and complex approach to physical education lessons.

Keywords: methodic, primary school, development, physical qualities
\end{abstract}

\section{Introduction}

Comprehensive physical education is one of the most important tasks of society. Formation of strong health and will, high workability and activity in physical culture lessons is the base of human intellectual development and physical perfection $[8,10,16,29]$. The main purpose of physical culture in educational system is provisioning of harmonious and comprehensive development of pupil's personality with high mental, physical and social activity $[5,17,28]$.

Active and persistent physical qualities' trainings accelerate and qualitatively change the process of all organism systems' development. Physical training with high quality is determined by level of main physical qualities fitness. It is the basis of workability in all kinds of educational, labor, applied and sport functioning.

Great number of scientific works is devoted to children's and adolescents' physical education effectiveness increase. Organizational-pedagogic and methodological basement of physical education system improvement for schoolchildren is regarded in scientific works in the following directions:

- Integration of cognitive and motor functioning in system of schoolchildren's teaching and education [3];

- Non traditional mobile games in schoolchildren's physical education [2];

- Systemizing of researches, used for determination of children's and athlete's physical condition, physical fitness and functional state [4];

- Ways of national schoolchildren's physical education system's formation [10];

- Study of motor functioning and its influence on motor abilities' level [13, 15].

The authors state that for 8 weeks it is possible

(c) Shuba L.V., 2017

doi:10.15561/18189172.2017.0207 to improve children's motor fitness with the help of Head Start program [14]. Application of other program (ATLAS) points at the fact that of obesity social-ecologic determinants can be wanted in order to avoid ill attention to adolescents' weight growth in societies with low income [30]. In such cases understanding of physical culture and its components significance is of decisive importance for working out and realization of effective measures among children [20]. Other results permit to assume that steady professional progress can give teacher knowledge and skills, required for increasing pupils' physical activity [33]. For increasing effectiveness of such approach it is necessary to offer the factors, which could support and stimulate teachers [19]. Besides, it is necessary to raise awareness in exercises as potential tool in teaching of movements' analyzing [24]. All these will permit to raise personal and social responsibility of a teacher. To achieve such results teachers shall develop and apply pedagogic strategies on constant base [23]. With it, school can not neglect sports, content and popularity of which is constantly increasing [21].

In other works the following aspects are studied:

- Modern approaches to organization and methodic of health related physical culture work with junior school age children, which could cultivate motivation for physical culture and facilitate increase of children's physical condition [5];

- Influence of general forms, methods and principles on training of motor skills, facilitating junior school age children's motor activity [22].

Application of different kinds of sports in primary schoolchildren's physical education is shown in the following directions:

- Optimization of 7-8 yrs children by light athletic means [1];

- Training of physical qualities of primary comprehensive school pupils (on example of strength 
and endurance) [7];

- Application of Ukrainian folk games in class and outof-class trainings [9];

- Formation of primary school pupils' motor skills in tennis training [12].

Application of mobile games is of great significance for children's motor skills, comprehensive physical development and health strengthening $[6,13]$. The authors proved that in physical education classes (during 5 weeks) with application of different types' tennis rackets, general coordination of arms and eyes improves [18]. For physical activity improvement it is offered to use game approach. It is proved by 7 weeks' observations over throws' motor skills and abilities to take decisions [31]. With it, it is necessary to consider distinctions between girls and boys $[24,32]$. It will permit to assess tests' adequacy in respect to schoolchildren's age $[25,27]$.

Analysis of publications showed that it is necessary to further substantiate influence of games, quantity of repetitions, rest intervals and their interactions on dynamic of primary school age children's motor skills. Solution of this problem will permit to perfect pupils' physical education and ensure their higher motor fitness.

The purpose of the research is to improve methodic of mobile games' application for physical culture lessons' optimization in primary school that would facilitate motor fitness increase.

\section{Material and methods}

Participant: in experiment 50 boys (7-9 yrs) from main health group (no health problems) participated. They were divided in control and experimental groups.

Organization of the research: the study was carried out in 2014 - 2015 academic year in countryside underfilled school. In control group trainings were conducted by traditional methodic, envisaging development only those physical qualities, which are required for successful mastering of motor techniques. In experimental group the trainings were carried out as per improved methodic.

Our experimental methodic was based on main principles of physical culture program for comprehensive educational establishments. The offered by us lessons were conducted by commonly accepted scheme, which consisted of three parts. But mobile games were selected so that they should maximally facilitate physical qualities development and pupils' motivation for regular physical culture practicing.

So, preparatory part was directed at organization of pupils, their familiarizing with content and preparation for main work. We used exercises with gradual increase of amplitude, quickness; with involving all large muscles’ groups in work.

For all experiment ten separate complexes of general exercises were planned (with objects and without object), which were fulfilled in game forms. It facilitated stimulation of motivation for training and pupils' attention during exercises' fulfillment.

In main part the following tasks were solved: primary school pupils' physical qualities' improvement during all experiment. When selecting games by character of motor functioning, the following motor actions were preferred: a walk, run, throws and jumps. Such games were included in physical education system for development of physical qualities (strength, quickness, endurance, dexterity, flexibility) and mental and will moral qualities.

For strength training we chose the games, which required short-term speed-power tensions, moderate by load. The following objects were used: filled ball, dump bells, benches or partners. In games with overcoming own weight we applied wall bars, benches or beams, vertical rope. Such games do not require special equipment. They envisage the following: moving on site resting be hands on floor (in lying position); back hands' resting on floor with jumping). The following games were used: "Who throws farther?", "Pushing the ball", "Keep in circle", "Attack", "Stronger circle", "Tilting doll", "Cockfighting" [7].

For quickness we used the games, which required instant reaction to sound, visual and tactile signals. Besides, we used games with sudden stops and starts; with covering short distances in the shortest possible time. Games for quickness were practiced in the first half of lesson and in little scopes. They were: "Call the number", "Black and white", "Wolf and sheep", "Simple tag", "Catch the ball”, "Ball's dribbling by circumference”, "Hunting ducks" [12].

For endurance the following games were used: games with repeated actions; with continuous motor functioning, connected with noticeable energy consumption. Children's age and physical fitness were considered. These games were practiced in the second part of lesson. Besides, we used the following games for endurance: "Fishers and fish", "Who is quicker?", "Catching of ball”, "Tiger ball”, "To push out", "Rugby", "Football on back", "Jumpers", "Catch me up" [7].

Dexterity was trained with the help of games, which force to pass quickly from one kind of actions to other, according to situation. They are: "Attentive eye”, "Falling tick”, "Ball above rope”, "Volleyball players’ passes”, "Only from below”, "and Bombardiers ”, “ Change of circles" $[1,3]$.

Flexibility is required in every movement. That is why high elasticity of muscles and ligaments facilitate good participation in game. For dexterity we used the following: "Who pass quicker?", "Who I quicker,"Bench above head", "Bridge and cat" [11].

At the end of game teacher called the best participants: who had the best dexterity, resolution, quickness; that observed rules and did not prevent other pupils from participation in the game. The teacher also called those, who violated rules. Finalizing of game was as usual in interesting form in order to stimulate pupils for even better results next lesson.

In final part of every lesson we practiced calm games, which did not require high attention and do not excite.

At every lesson three main kinds of movements were fulfilled. They were repeated in certain sequence, varying after comparatively short period of time. With it movements' compatibility was very important. 
At the beginning and at the end of the research all pupils passed control tests for physical condition and physical fitness.

Dexterity was determined in test "Shuttle run $4 \times 9$ " (sec.): testing result was the time from start to the moment when participant put cube in start semi-circumference. The time was registered in the best attempt from two.

Quickness was tested with test “30 meters' run” (sec.): testing result was time of distance covering, fixed with stopwatch. Only one attempt was admitted.

Speed power was registered in test "Long jump from the spot” (m): result was the length of jump in centimeters. The best result from two attempts was registered.

Arm muscles' strength was tested with "Pressing ups in lying position" (quantity of times). When fulfilling this exercise, the tested shall touch tennis ball by chest. Maximal quantity of touches was the result of test.

Flexibility was found with the test "Forward bend from standing position" $(\mathrm{cm})$. The tested was barefoot (distance between feet was 20-30 cm). Knees shall not be bent. The bent was controlled by other pupil. By command "Go" the tested bent forward trying to stretch arms as far as possible. The bent shall be kept 2-3 seconds, touching mark with fingers.

Statistical analysis: we calculated mean arithmetic, mean square deviation, variation coefficient, standard error of mean arithmetic, correlation coefficient. The received data were processed with Microsoft Excel program.

\section{Results}

In modern society we can observe weakening of population's health and reduction of life span. One of the most promising directions of physical education's optimization is rational usage of effective means and methods; improvement of school age children's motor abilities for their physical condition strengthening and their health improvement $[13,15]$. In this connection, theory and methodic of physical education in comprehensive school have been progressing rather noticeable recent time. They are supplemented with new data and become still more practical. However, the wanted result can be achieved only under reasonable administrating of pedagogic process, considering physical qualities and motivation for physical culture development. Especially important becomes selection of health related physical education means and methods.

In table 1 we present testing indicators of 7-9 yrs boys' physical qualities before and after experiment.

Analysis of results showed that the groups are more homogeneous by indicators of the following tests: 30 meters' run, shuttle run $4 \times 9 \mathrm{~m}$, long jump from the spot, pressing ups in lying position.

Test results after experiment show that in all tested groups there was increment in physical qualities. With it, their values and direction are not the same in different groups. In experimental group all indicators improved. In control groups some indicators improved and some - not.

In test “30 meters' run” indicators increased more in experimental group as well as indicators of "Shuttle run $4 \times 9 \mathrm{~m}$ ". High results were received also in test "Forward torso bending from standing position".

It should be noted that for effective development of physical qualities a decisive factor was consideration of sensitive periods and complex approach to physical training. Besides, we analyzed percentage of physical qualities' indicators increment before and after experiment (see fig. 1).

Analysis of indicators (see fig. 1) permits to say that implementation of improved methodic in physical culture lessons facilitated development of main physical qualities and increased children's motivation for physical culture.

This analysis also shows that application of mobile games in pupils' physical fitness training gave higher increment in all groups. Percentage increment in experimental groups was $22.72 \%$; in control groups it was $9.75 \%$. Thus, the received results witness about effectiveness of improved methodic of physical culture lessons for 7-9 yrs boys with preference of mobile games.

\section{Discussion}

Mobile games are rather important for general development of children. Their value is the following: development of children's natural movements, which are still imperfect in this age; facilitation of children's higher activity for achievement of success [2, 3, 9, 11]. The authors state that mobile games also stimulate attention, memory and power of observation. Such games are also a peculiar form of world cognition. They satisfy their cognitive, social, moral and aesthetic demands. Thus, mobile games shall take significant place in life of primary schoolchildren. Application of mobile games corresponds to children's age characteristics.

In games children try to act in the most rational way and maximally mobilize all efforts for achievement of the best result. Moral and will qualities are also manifested in such games. Requirements to exact observation of rules facilitate cultivation of discipline, self-restraint and responsibility in children. However, it does not restrict prospects for initiative, activity and inventiveness in mobile games at lessons [9].

At lessons we used different by content mobile games. For trainings we chose story games, relay races and games with elements of sports, in which the players shall be distributed by teams. The game roles were played by children. It activated children's game actions and facilitated increase of interest in physical culture lessons.

The main task of our improved methodic was provisioning of child's full fledged development. The methodic included the following: keeping of interconnection and inter-conditioning of all forms of organization and kinds of motor activity; persistent development of all motor qualities; cultivation of children's responsible attitude to accuracy and correctness of movements; children's teaching to analyze (control an assess) own movements and movements of their classmates; creativity and motor activity; independent organization of mobile games and exercises; consideration 
Table 1. Static indicators of 7-9 yrs boys' motor abilities before and after experiment

\begin{tabular}{|c|c|c|c|c|c|c|c|c|c|c|c|c|c|}
\hline \multirow{4}{*}{$\begin{array}{l}\text { Description } \\
\text { of tests }\end{array}$} & \multirow{4}{*}{ 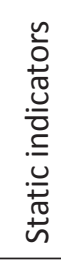 } & \multicolumn{6}{|c|}{ Boys control group } & \multicolumn{6}{|c|}{ Boys experimental group } \\
\hline & & \multirow{2}{*}{\multicolumn{2}{|c|}{ 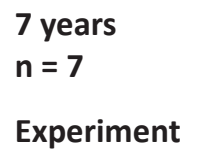 }} & \multicolumn{2}{|c|}{$\begin{array}{l}8 \text { years } \\
n=8\end{array}$} & \multicolumn{2}{|c|}{$\begin{array}{l}9 \text { years } \\
n=10\end{array}$} & \multirow{2}{*}{\multicolumn{2}{|c|}{$\begin{array}{l}7 \text { years } \\
n=7 \\
\text { Experiment }\end{array}$}} & \multirow{2}{*}{\multicolumn{2}{|c|}{$\begin{array}{l}8 \text { years } \\
n=8\end{array}$}} & \multirow{2}{*}{\multicolumn{2}{|c|}{$\begin{array}{l}9 \text { years } \\
n=10\end{array}$}} \\
\hline & & & & & & & & & & & & & \\
\hline & & before & after & before & after & before & after & before & after & before & after & before & after \\
\hline \multirow{5}{*}{$\begin{array}{l}30 \text { meters' } \\
\text { run sec. }\end{array}$} & $\bar{x}$ & 6.87 & 6.20 & 6.10 & 5.90 & 5.96 & 5.66 & 6.89 & 5.70 & 6.10 & 5.40 & 5.97 & 5.10 \\
\hline & $\sigma$ & 0.63 & 0.53 & 0.49 & 0.79 & 0.35 & 0.35 & 0.61 & 0.51 & 0.63 & 0.73 & 0.40 & 0.54 \\
\hline & V & 9.14 & 8.13 & 8.04 & 8.97 & 8.91 & 8.41 & 8.36 & 8.16 & 9.67 & 8.67 & 8.34 & 8.99 \\
\hline & $\mathrm{m}$ & 0.12 & 0.10 & 0.07 & 0.17 & 0.04 & 0.14 & 0.16 & 0.14 & 0.09 & 0.19 & 0.04 & 0.16 \\
\hline & $\bar{x}$ & 12.12 & 12.07 & 11.63 & 11.53 & 11.34 & 11.24 & 12.14 & 12.00 & 11.73 & 11.40 & 11.30 & 11.10 \\
\hline \multirow{4}{*}{$\begin{array}{l}\text { Shuttle run } \\
4 \times 9 \text { m. sec. }\end{array}$} & $\sigma$ & 0.74 & 0.70 & 0.70 & 0.79 & 0.71 & 0.74 & 0.49 & 0.69 & 0.68 & 0.71 & 0.81 & 0.75 \\
\hline & V & 6.10 & 4.14 & 6.05 & 5.05 & 6.22 & 5.22 & 6.70 & 5.70 & 5.59 & 5.93 & 6.76 & 5.76 \\
\hline & $\mathrm{m}$ & 0.14 & 0.15 & 0.10 & 0.16 & 0.09 & 0.19 & 0.13 & 0.16 & 0.10 & 0.11 & 0.09 & 0.19 \\
\hline & $\bar{x}$ & 118 & 133 & 137 & 141 & 141 & 150 & 128 & 140 & 136 & 150 & 140 & 158 \\
\hline \multirow{3}{*}{$\begin{array}{l}\text { Long jump } \\
\text { from the } \\
\text { spot, cm }\end{array}$} & $\sigma$ & 5.55 & 4.55 & 5.88 & 4.81 & 5.61 & 4.11 & 5.49 & 4.39 & 5.17 & 4.17 & 5.08 & 4.12 \\
\hline & V & 9.59 & 7.51 & 9.49 & 7.40 & 9.18 & 7.18 & 9.58 & 7.48 & 9.66 & 7.86 & 9.26 & 7.06 \\
\hline & $\mathrm{m}$ & 2.52 & 2.42 & 2.25 & 2.25 & 2.26 & 3.16 & 3.23 & 2.13 & 2.40 & 2.40 & 1.80 & 3.00 \\
\hline \multirow{4}{*}{$\begin{array}{l}\text { Forward } \\
\text { torso } \\
\text { bending, } \\
\text { cm }\end{array}$} & $\bar{x}$ & ,7 & 7.1 & 5.3 & 6.9 & 6.0 & 8.7 & 5.6 & 9.0 & 5.4 & 10.1 & 6.1 & 11.4 \\
\hline & $\sigma$ & 6.51 & 6.11 & 6.30 & 6.10 & 6.92 & 6.12 & 6.07 & 6.07 & 6.49 & 6.49 & 6.98 & 6.38 \\
\hline & V & 8.09 & 5.04 & 8.25 & 5.15 & 8.63 & 5.33 & 8.21 & 5.29 & 8.12 & 5.45 & 8.66 & 5.56 \\
\hline & $\mathrm{m}$ & 1.21 & 1.44 & 0.89 & 1.11 & 0.84 & 0.95 & 1.83 & 1.14 & 0.91 & 1.27 & 0.57 & 0.77 \\
\hline \multirow{4}{*}{$\begin{array}{l}\text { Pressing } \\
\text { ups in lying } \\
\text { position, } \\
\text { quantity of } \\
\text { times }\end{array}$} & $\bar{x}$ & 15 & 16 & 16 & 17 & 17 & 18 & 15 & 18 & 16 & 20 & 17 & 22 \\
\hline & $\sigma$ & 4.07 & 4.17 & 4.99 & 4.19 & 5.22 & 5.22 & 4.50 & 4.02 & 4.93 & 4.85 & 5.56 & 5.56 \\
\hline & V & 6.74 & 7.76 & 6.25 & 7.95 & 6.71 & 7.41 & 6.27 & 7.72 & 6.65 & 7.65 & 6.89 & 7.89 \\
\hline & $\mathrm{m}$ & 1.31 & 2.13 & 0.99 & 0.81 & 0.10 & 1.29 & 1.16 & 2.14 & 0.69 & 0.75 & 0.73 & 1.41 \\
\hline
\end{tabular}

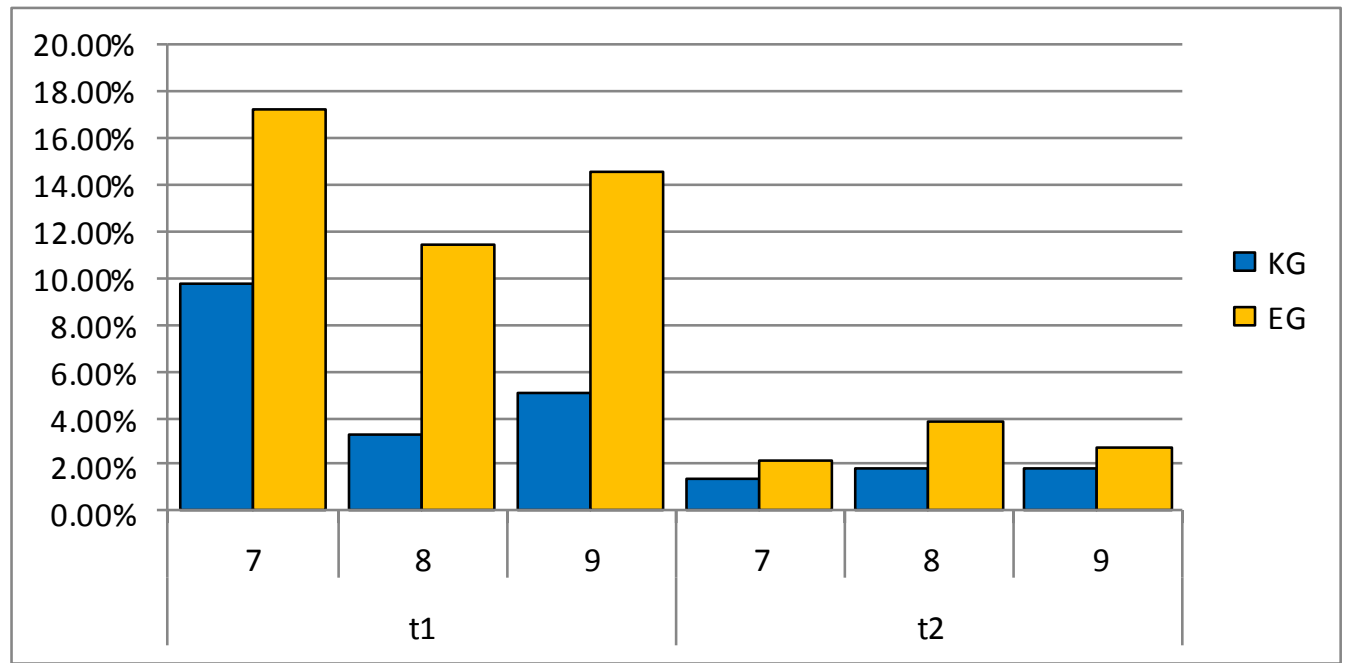

Fig.1. Percentage increment of physical qualities' indicators in control (CG) and experimental (EG) groups. 7, 8, 9- age in years, $L-$ Long jump from the spot $(\mathrm{cm})$; $M$ - Forward torso bending from standing position $(\mathrm{cm})$, CG - control group, EG - experimental group; t1 - 30 meters' run (sec.); t2 - Shuttle run 4x9 m (sec.); A - Pressing ups in lying position (quantity of times). 

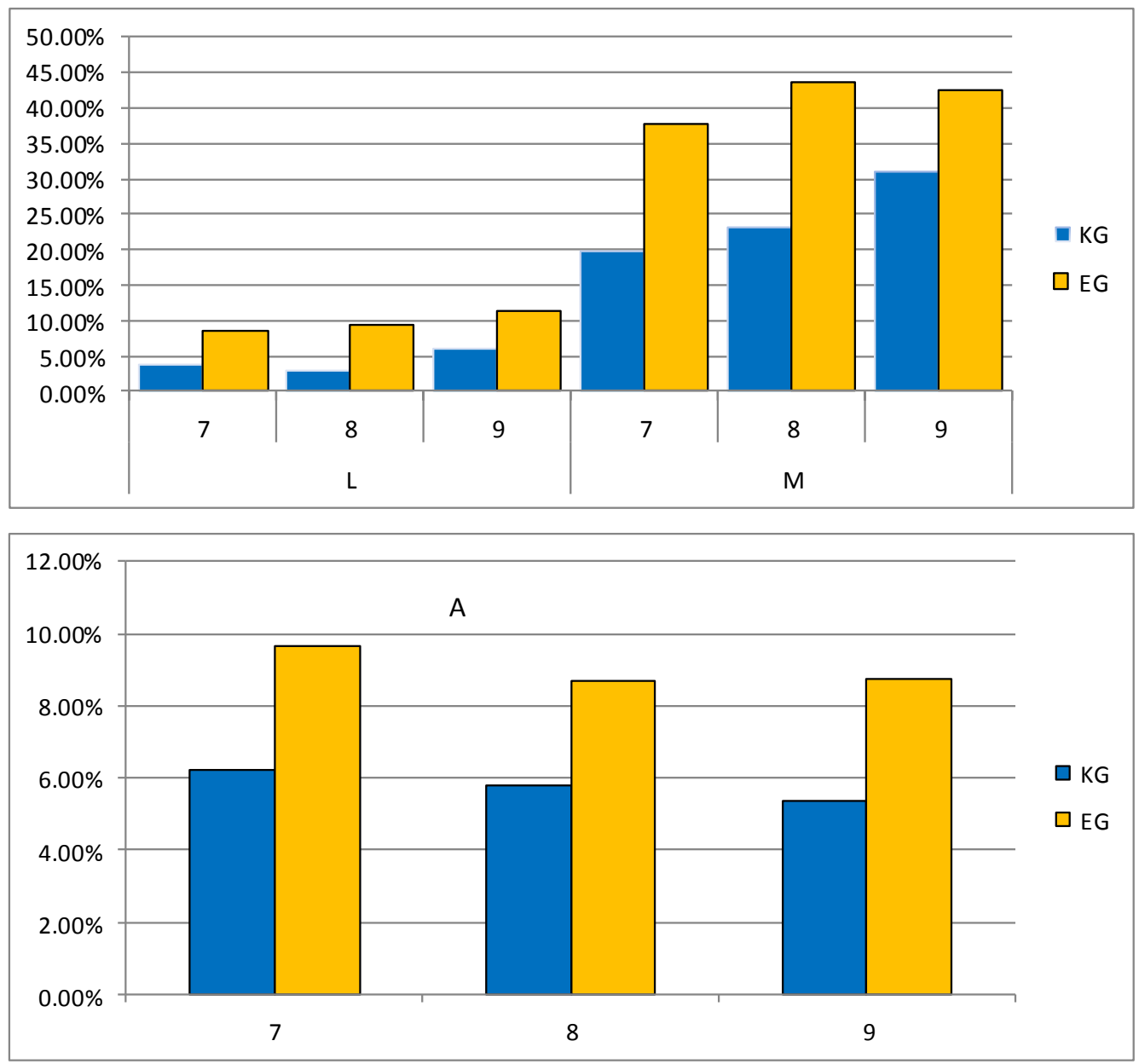

Fig.1. Percentage increment of physical qualities' indicators in control (CG) and experimental (EG) groups. 7, 8, 9- age in years, L - Long jump from the spot $(\mathrm{cm}) ; \mathrm{M}$ - Forward torso bending from standing position $(\mathrm{cm}), \mathrm{CG}-$ control group, EG - experimental group; t1 - 30 meters' run (sec.); t2 - Shuttle run 4x9 m (sec.); A - Pressing ups in lying position (quantity of times).

of child's age and individual characteristics; facilitation to positive emotional-psychological climate; formation of ideas about healthy life style; importance of hygienic and motor culture $[6,8,10]$.

Analysis of the received data showed that increment of results was in all indicators. The highest increment was in test "Forward torso bending from standing position" and "30 meters' run”. It is connected with sensitive period of quickness and flexibility development. These data prove results of other authors $[1,4,5]$. With it, it is necessary to observe all principles and structures of pedagogic process. It witnesses that we considered this aspect also, when creating our methodic.

\section{Conclusions:}

Analysis of scientific methodic literature showed that main problem is seeking of innovative approaches to physical exercises' practicing, considering children's interests and age characteristics. It facilitated improvement of mobile games application methodic at physical culture lessons for 7-9 yrs. children. Special aspects of the improved methodic are the following: ten complexes of general exercises in game form for preparatory part; for all parts of training mobile games were selected so that they should maximally facilitate physical qualities' development; every training had positive emotional coloring that facilitated pupils wish to constantly attend the lessons.

The prospects of further researches are connected with study of schoolchildren's with different health adaptation to physical loads under influence of mobile games; further study of personality-oriented approach to physical education of primary school pupils with accent on memory, thinking, attention,. Physical qualities and motor skills increment and health strengthening.

\section{Conflict of interests}

The author declares that there is no conflict of interests. 


\section{References}

1. Borejko MM. Optimizaciia fizichnogo vikhovannia ditej 7-8 rokiv zasobami legkoi atletiki. Kand. Diss. [Optimization of 7-9 yrs children's physical; education by light athletic means. Cand. Diss.], Ternopil; 2001. (in Ukrainian)

2. Vas'kov IuV. Netradicijni rukhlivi igri v sistemi fizichnogo vikhovannia uchniv [Non traditional mobile games in physical education system of schoolchildren], Kharkiv: Morning; 2010. (in Ukrainian)

3. Dubogaj OD, Pangelov BP, Frolova NO, Gorbenko MI. Integraciia piznaval'noi $i$ rukhovoi diial'nosti $v$ sistemi navchannia $i$ vikhovannia shkoliariv [Integration of cognitive and motor functioning insystem of schoolchildren's educational and teaching system]. Kiev: Oriyana; 2001. (in Ukrainian)

4. Krucevich TIu. Metody issledovaniia individual'nogo zdorov'ia detej $i$ podrostkov $v$ processe fizicheskogo vospitaniia [The methods of study of children's and adolescents' individual health in physical education process], Kiev: Olympic Literature; 1999. (in Russian)

5. Moskalenko NV. Fizichne vikhovannia molodshikh shkoliariv [Physical education of primary schoolchildren], Dnepropetrovsk: Innovation; 2007. (in Ukrainian)

6. Pal'chevs'kij SS. Pedagogika [Pedagogic], Kiev: Caravel; 2007. (in Ukrainian)

7. Prisiazhniuk SI. Rozvitok fizichnikh iakostej uchniv pochatkovikh klasiv zagal'noi shkoli. Kand. Diss. [Development of comprehensive primary schoolchildren's physical qualities. Cand. Diss.], Lviv; 2001. (in Ukrainian)

8. Diatlenko SM. Fizichna kul'tura $v$ shkoli [Physical culture in school], Kiev: Letter LTD; 2009. (in Ukrainian)

9. C'os' AV. Ukrains'ki narodni igri ta zabavi [Ukrainian folk games and amusements], Lutsk: Naddnistrov'ya; 1994. (in Ukrainian)

10.Shiian BM. Teoriia $i$ metodika fizichnogo vikhovannia shkoliariv [Theory and methodic of schoolchildren's physical education], Ternopil: Educational book, Bohdan; 2007. (in Ukrainian)

11.Shuba LV. Rukhlivi igri iak zasib rozvitku rukhovikh iakostej u shkoliariv pochatkovoi shkoli [Mobile games as method of motor qualities' development in primary schoolchildren]. Nauka i osvita, 2014;8:212 - 216. (in Ukrainian)

12.Shuba LV. Formuvannia rukhovikh umin' ta navichok uchniv pochatkovoi shkoli u procesi zaniat' tenisom [Formation of motor skills of primary schoolchildren in process of tennis trainings]. Zaporozhye: LLC "Lips" LTD; 2015. (in Ukrainian)

13.Shuba L.V. Modern approach to implementation of health related technology for primary school children. Pedagogics, psychology, medical-biological problems of physical training and sports, 2016; 2:66 - 71. doi:10.15561/18189172.2016.0210 (in Ukrainian)

14.Altunsoz IH, Goodway JD. SKIPing to motor competence: the influence of project successful kinesthetic instruction for preschoolers on motor competence of disadvantaged preschoolers. Physical Education and Sport Pedagogy. 2016;21(4):366-85

15.Apache RR. Activity-based intervention in motor skill development. Percept Mot Skills. 2005; 100 (3 Pt 2): 1011-20.

16.Arziutov G, Iermakov S, Bartik P, Nosko M, Cynarski WJ. The use of didactic laws in the teaching of the physical elements involved in judo techniques. Ido Movement for Culture, 2016;16(4):21-30. doi:10.14589/ido.16.4.4

17.Bliznevsky AA, Kudryavtsev MD, Iermakov SS, Jagiello W.
Formation of active-effective attitude of 12-13 years' judo athletes to sports functioning in competition period. Archives of Budo. 2016;12:101-15.

18.Buszard T, Reid M, Masters RSW, Farrow D. Scaling Tennis Racquets During PE in Primary School to Enhance Motor Skill Acquisition. Research Quarterly for Exercise and Sport. 2016;87(4):414-20.

19.Carse N. Primary teachers as physical education curriculum change agents. European Physical Education Review. 2015;21(3):309-24.

20.Ceschia A, Giacomini S, Santarossa S, Rugo M, Salvadego D, Da Ponte A, et al. Deleterious effects of obesity on physical fitness in pre-pubertal children. European Journal of Sport Science. 2016;16(2):271-8.

21.Fernandez-Rio J, Suarez C. Feasibility and students' preliminary views on parkour in a group of primary school children. Physical Education and Sport Pedagogy. 2016;21(3):281-94

22.Fisher JJ, Reilly LA, Kelly C, Montgomery A, Williamson JY. Fundamental movement skills and habitual physical activity in young children. Med Sci Sports Exerc, 2005. 37; pp. 684-688.

23.Garcia-Lopez LM, Gutierrez D. The effects of a sport education season on empathy and assertiveness. Physical Education and Sport Pedagogy. 2015;20(1):1-16.

24.Haynes J, Miller J. Preparing pre-service primary school teachers to assess fundamental motor skills: two skills and two approaches. Physical Education and Sport Pedagogy. 2015;20(4):397-408.

25.Ivashchenko OV, Kapkan OO. Informative pedagogic control indicators of 14-15 years age girls' motor fitness. Pedagogics, psychology, medical-biological problems of physical training and sports, 2016; 20(6): 18-25. doi:10.15561/18189172.2016.0603

26.Ivashchenko OV, Yermakova TS. Structural model of in-group dynamic of 6-10 years old boys' motor fitness. Pedagogics, psychology, medical-biological problems of physical training and sports, 2015; 19(10): 24-32. doi:10.15561/18189172.2015.1004

27.Ivashchenko OV. Special aspects of motor fitness influence on level of 11-13 years' age girls' physical exercises' mastering. Pedagogics, psychology, medical-biological problems of physical training and sports, 2017; 21(1): 11-17. doi:10.15561/18189172.2017.0102

28.Khudolii OM, Ivashchenko OV, Iermakov SS, Rumba OG. Computer simulation of Junior gymnasts' training process. Science of Gymnastics Journal, 2016;8(3):215-228.

29.Kozina ZL, Iermakov SS, Kadutskaya LA, Sobyanin FI, Krzeminski M, Sobko IN, Ryepko OA. Comparative characteristic of correlation between pulse subjective indicators of girl students' and school girls' reaction to physical load. Physical Education of Students. 2016;20(4):2434. doi:10.15561/20755279.2016.0403

30.Lubans DR, Smith JJ, Plotnikoff RC, Dally KA, Okely AD, Salmon J, et al. Assessing the sustained impact of a schoolbased obesity prevention program for adolescent boys: the ATLAS cluster randomized controlled trial. International Journal of Behavioral Nutrition and Physical Activity. 2016;13.

31.Miller A, Christensen E, Eather N, Gray S, Sproule J, Keay J, et al. Can physical education and physical activity outcomes be developed simultaneously using a gamecentered approach? European Physical Education Review. 2016;22(1) 
32.Platvoet SWJ, Elferink-Gemser MT, Kannekens R, de Niet M, Visscher C. Four Weeks of Goal-Directed Learning in Primary Physical Education Classes. Perceptual and Motor Skills. 2016;122(3):871-85.
33.Stylianou M, Kulinna PH, Naiman T. '...because there's nobody who can just sit that long': Teacher perceptions of classroom-based physical activity and related management issues. European Physical Education Review. 2016;22(3):390-408.

\section{Information about the author:}

Shuba L.V.; http://orcid.org/0000-0002-8037-4218; mila-shuba@yandex.ru; Zaporozhye National Technical University; street Zykovskogo, 64, Zaporozhye, 69063, Ukraine.

Cite this article as: Shuba L.V. Optimization of physical culture lessons in primary school on the base of mobile games' application. Pedagogics, psychology, medical-biological problems of physical training and sports, 2017;2:87-93. doi:10.15561/18189172.2017.0207

The electronic version of this article is the complete one and can be found online at: http://www.sportpedagogy.org.ua/index.php/PPS/issue/archive

This is an Open Access article distributed under the terms of the Creative Commons Attribution License, which permits unrestricted use, distribution, and reproduction in any medium, provided the original work is properly cited (http://creativecommons.org/licenses/by/4.0/deed.en).

Received: 09.01.2017

Accepted: 16.01.2017; Published: 30.04.2017 